\begin{tabular}{|c|c|}
\hline & Volume \& Issues Obtainable at The Women University Multan \\
Annals of Social Sciences and Perspective \\
ISSN: 2707-7063, Volume 2, No.2 December 2021
\end{tabular}

\title{
Institutional and Non-Institutional Determinants of Volatile Non- Systematic Discretionary Spending: A Panel Data Analysis
}

\begin{tabular}{|c|c|}
\hline \multicolumn{2}{|c|}{ Farhat Rasul $^{1}$, Nabila Asghar ${ }^{2}$, Hafeez Ur Rehman ${ }^{3}$} \\
\hline \multicolumn{2}{|c|}{$\begin{array}{l}{ }^{1} \text { Assistant Professor, Department of Economics and Statistics, HSM. University of Management and } \\
\text { Technology, Lahore, Pakistan } \\
{ }^{2} \text { Associate Professor, Department of Economics and Business Administration, Division of Management and } \\
\text { Administrative Science, University of Education, Lahore, Pakistan } \\
\text { 3Professor/ Chairman, Department of Economics and Statistics. HSM. University of Management and } \\
\text { Technology, Lahore, Pakistan }\end{array}$} \\
\hline ARTICLE DETAILS & ABSTRACT \\
\hline $\begin{array}{lr}\text { History: } & \\
\text { Received: } & 25 \text { August, } 2021 \\
\text { Review: } & 13 \text { October, } 2021 \\
\text { Accepted: } & 13 \text { November, } 2021 \\
\text { Available } & \text { Online: } 13 \text { November, } 2021\end{array}$ & $\begin{array}{l}\text { The volatile and patchy nature of discretionary public } \\
\text { spending has different implications for overall } \\
\text { economic performance. The present study examines the } \\
\text { institutional and non-institutional features of non- } \\
\text { systematic discretionary public spending. The study } \\
\text { considers a panel of } 55 \text { economies from } 1990 \text { to } 2019\end{array}$ \\
\hline $\begin{array}{l}\text { Keywords: } \\
\text { Volatility, Non-systematic } \\
\text { Discretionary Spending, GMM. }\end{array}$ & $\begin{array}{l}\text { and applies GMM estimation technique. The findings } \\
\text { suggest that in the aggregated sample, constraints on } \\
\text { executives, government stability, bureaucratic quality, }\end{array}$ \\
\hline O/assap.v2i2.53 & $\begin{array}{l}\text { economic growth, and size of a nation significantly } \\
\text { decrease the instability in non-systematic discretionary } \\
\text { public spending; but, presidential system, corruption, } \\
\text { and openness of economies promote such spending } \\
\text { volatility. Furthermore, disaggregated analysis } \\
\text { suggests that in developing economies, constraints on } \\
\text { executives become insignificant to lower discretionary } \\
\text { public spending volatility, while, in developed } \\
\text { economies, the presidential system and corruption } \\
\text { appear insignificant to promote volatility in non- } \\
\text { systematic discretionary spending. } \\
\text { @ } 2021 \text { The Authors, Published by WUM. This is an Open Access } \\
\text { article under the Creative Common Attribution Non Commercial } 4.0\end{array}$ \\
\hline
\end{tabular}

Corresponding author's email address: hafeez.rehman@umt.edu.pk

\section{Introduction}

Over the last few decades, a significant expansion has been recorded in public spending. Where such expansion is observed to translate into a higher level of public debt and the budget deficit (Barro, 1979; Sinha et al. 2011). Subsequently, fiscal literature inquires factors, which lead to fiscal deterioration. Nevertheless, fiscal discretion - a deliberate change in spending policy; which is responsible for aggressive use of spending and causes fiscal deterioration is omitted dimension in the fiscal research agenda (Albuquerque, 2011; Fatás \& Mihov, 2009). The public authorities use two types of discretion in spending; the 
'systematic discretion', which is used to smooth out fluctuations in the business cycle to correct the path of investment and growth (Furceri \& Poplawski Ribeiro, 2008), and 'nonsystematic discretion', which is executed as independent of business cycle fluctuations (Fatás \& Mihov, 2003). The latter part, which is primarily used for political motives is observed volatile, as evident from figure A1 in the appendix.

Volatility in non-systematic discretionary spending is believed to have severe macroeconomic consequences. For instance, such policy volatility generates macroeconomic uncertainty, which adversely affects the decisions of investors and economic agents and retards economic growth (Albuquerque, 2011; Ali, 2005; Fatás \& Mihov, 2009). Therefore, a question arises, whether constraints should be imposed on public authorities to limit discretionary powers. There exist two opinions in this regard: one view suggests that restrictions on fiscal authorities could shrink adverse growth consequences of higher policy volatility triggered by the unbounded fiscal plan (Alesina \& Bayoumi, 1996). Nevertheless, the other view suggests that though restrictions could shrink volatility; however, reduces the ability of fiscal authorities to deal with business cycle fluctuations (Lane, 2003). Thus, restrictions delay economic adjustment to unobserved shocks (Ali, 2005; Alt \& Lowry, 1994).

The political economy literature extensively discusses the motives of fiscal authorities to use discretion in fiscal instruments. There exists a consensus in the literature that volatility in discretionary spending obliterates monetary commitment (Dixit \& Lambertini, 2001), promotes output volatility (Badinger, 2009), and harms economic growth (Fatas \& Mihov, 2013). Generally, the economies, which follow more discretionary measures coupled with the large budget deficit, and unstable exchange rates face higher instability and lower economic growth (Acemoglu et al. 2003). Despite the higher economic cost, an exclusive institutional structure often motivates office-bearers to exercise discretion in policies. Consequently, with pro-growth and stabilizing characteristics, fiscal measures become the source of macroeconomic instability.

Now, what can be done to restrain authority holders from unnecessary volatile discretionary spending? To answer the question, literature proposes the formation and implementation of budgetary institutions, i.e., designing measures, which keep check and balance over the matter of public finance. Soetjipto, et al. (2020) provide a basis for encouraging public sector performance to smoothly all the government projects, especially in the area of public services. Additionally, the matter is associated with fiscal and even political institutions, which shape the behavior of economic decisions (Persson, 2002; Persson \& Tabellini, 2001). Therefore, institutional change is required to ensure policy stability. The idea of strengthening the structure of institutions ranges from simple arrangments to comprehensive accountability and transparency of underlying policies. This implies that to precise deicide about the volume of the budget deficit, the authority should be handed over to the autonomous committee (Wyplosz, 2005). Nevertheless, in certain situations political factors do not reduce the volatility of discretionary policy, yet, size of government and quality of institutions seem to have significant implications for discretionary fiscal volatility (Albuquerque, 2011).

Driven from the discussion, non-systematic discretionary spending is an undesirable part of public spending. Although, its economic consequences are well explored; however, the factors, which shape the behavior of such spending are largely ignored (Fatás \& Mihov, 2003; Albuquerque, 2011). The present study inquires about the institutional and noninstitutional factors that affect non-systematic discretionary spending. This study contributes to the existing literature in several ways. Firstly, this study decomposes total public spending and calculates a precise measure of non-systematic discretionary spending, which is not associated with business cycle fluctuations. To do this, the study amends the fiscal rule model 
of Fatás and Mihov (2003) by including additional control variables such as the size of the nation, public debt, and tax revenue. Secondly, this study calculates the unconditional and conditional volatility of non-systematic discretionary spending for each entity (economy). Third, this study searches factors that shape the structure of non-systematic discretionary spending for both the aggregated sample of economies and also for the disaggregated samples of developed and underdeveloped economies. Through the disaggregate analysis, the study controls the bias caused by the diversified nature of two sets of economies. Finally, this study conducts a robust check by employing different panel estimation methods; however, rely on the estimates of Generalized Method of Moment (GMM), to overcome the problem of endogeneity in regressions.

\section{Literature Review}

\subsection{Discretion in Fiscal Policy}

A systematic body of the political economy literature attempts to bring the structures of political institutions to the spheres of economics and together make it clear to understand the outcomes of any economic policy. The literature explains that fiscal policy is not always executed by benevolent governments; rather such policy is framed by political actors who have certain political objectives. To put it differently, the political actors to achieve political mileage create higher variation in fiscal parameters compared to what is needed if authorities react only to cyclical shocks. Thus, despite a growth-stimulating driver, such kind of behavior results in unfavorable fiscal's plans, which creates macroeconomic uncertainty. Hence, the question arises of what inspires fiscal authorities to exercise discretion in fiscal policy.

Additionally, other studies on the issue, such as Fatás and Mihov (2009), Albuquerque (2011), and Alesina and Drazen (1989) inquire about the issue in more dynamic settings. These studies suggest that restrictions on fiscal authorities and the concentration of government powers can significantly define the structure of non-systematic expenditure. Consequently, two main questions are addressed by literature. First, why there occur changes in fiscal policy. Second, one should be aware of the existing political and institutional setup in a country to comprehend, why some governments prefer to use more discretion in fiscal measures than others.

\subsection{The Need for Restraining Discretion in Fiscal Policy}

Enormous literature provides evidence about undesirable economic outcomes as a result of substantial volatility caused by the aggressive use of discretionary fiscal measures. For instance, Fatás and Mihov (2003, 2009) and Badinger (2009) provide suggestive evidence that output volatility is strongly influenced by the level of discretionary fiscal measures. This undesirable situation supports the imposition of constraints on fiscal authorities to ensure economic stability instead of leaving them unrestricted. As often, monetary decisions are handed over to independent central banks to avoid high inflationary pressure and improve monetary discipline. Nevertheless, there exists no consensus among policymakers to restrict fiscal authorities from aggressive use of discretionary measures (Albuquerque, 2011). Generally, policies are considered in "rules versus discretion" settings, where debate centers around the substitution between flexibility and regulation. In such circumstances, the policy makers have only one option, i.e., to use the fiscal policy to accomplish their political goals.

Considering this dimension, a considerable amount of literature supports the idea of strengthening budgetary institutions, i.e., devising the rules that keep check and balance over 
public finance. This rapid attention to improving feature of institutions are supported by the following views. First, institutions directly affect policy preferences, because restrictions in legislation place conditions on fiscal measures. Second, appropriate institutions reduce or abolish the high budget deficit. Third, the desired economic growth could be achieved in presence of quality institutions (Henisz, 2000).

Nevertheless, restrictions on fiscal policy are debatable and controversial. The proponents of discretion in fiscal policy argue that limiting the power of fiscal authorities would reduce their ability to deal with any unobserved shock. Lane (2003) proposes that limiting the fiscal policy promotes pro-cyclicality. In contrast, the authors like Fatás and Mihov (2003, 2009), Alesina and Bayoumi (1996), and Poterba (1994) suggest that political agents generate high deficits and create higher volatility. This instability can be corrected by imposing limits on fiscal authorities. This restriction ranges from numerical fiscal rules to procedural rules (Hallerberg et al. 2007; Fabrizio \& Mody, 2006; Yläoutinen, 2004; Gleich, 2003; Debrun et al. 2008). They discussed literature agrees that the nature of constraints is valuable to improve fiscal discipline.

Additionally, adverse impact channelized through political and institutional setup (Fatas \& Mihov, 2013). Alternatively, strong institutions, which impose higher restrictions on fiscal authorities ensure the stability of policy. This in turn stabilizes private investment, which translates into higher economic growth. Hence, a favorable institutional setup could be used as an apparatus to avoid aggressive policy measures. The strategy to build quality institutions starts from the straightforward measures of increasing transparency in polices formation and accountability of public authorities. In other words, an independent competent agency should decide about changes in fiscal parameters and the size of the budget deficit (Wyplosz, 2005).

In literature, the term restriction appears with the term fiscal institutions or simply "institutions". This covers different dimensions of the social political and economic arrangement of a country, which considerably shapes the direction of any policy. Additionally, such features encompass a range of themes related to political and institutional procedures. The given studies incorporate implicit limits, like procedural rules, and explicit limits, (e.g managing budgetary process, numerical fiscal rules, arrangement of the electoral system), political setup (presidential or parliamentary), ideological preferences, and political parties concentration in parliament.

\subsection{Empirical Review}

There exist studies such as, Afonso and Hauptmeier (2009), Debrun et al. (2008), Hallerberg et al. (2007), Annett (2006), Wyplosz, 2005), Fabrizio and Mody (2006), Persson (2002), Henisz, 2000 and Persson and Tabellini (2001) that inquired the factors of the budget deficit and subsequent accumulation of public debt. While the other studies, like Fatás and Mihov (2003, 2009), Lane (2003) investigated the cyclicality of fiscal policy, i.e., the response capacity of fiscal authorities to output shock. Hence, few studies have unfolded the issue related to policy volatility. Nevertheless, the literature specifically on discretionary fiscal volatility is still very scarce except for Fatás and Mihov (2003, 2009), Afonso et al. (2010), and Albuquerque (2011).

Fatás and Mihov $(2003,2009)$ investigate the cost of volatile discretionary policies and the factors that determine such spending volatility. The authors observe in a large sample of countries that volatility in discretionary spending promotes substantial instability in the macroeconomic system and retards average economic growth. These findings hold even after 
controlling endogeneity through Two Stage Least Square (2SLS) and Generalized Method of Moment (GMM). Additionally, they note that such policy is significantly correlated to political and institutional setup in a country, i.e., the countries with presidential systems and lower political constraints on the policymakers continue with more aggressive and volatile discretionary spending. Recently, Ali and Khan (2020) inquire about the cost of a volatile discretionary public expenditure system in a large panel of advanced and emerging economies. They also observe that such spending volatility is strongly influenced by the political system (presidential or political system, number of elections, and concentration of the government in the parliament) and historical institutional setup which is shaped by the settler's mortality rate. Similarly, Khan et al. (2019) examine the macroeconomics consequences of discretionary spending volatility in a large panel of economies. The authors use the GMM estimation technique and observe that such spending volatility adversely affects economic growth. Additionally, they observe that discretionary spending volatility is primarily influenced by the political institutions, therefore, the fiscal authorities should be restrained through effective fiscal rule, i.e., numerical constraints on spending. Likewise, Albuquerque (2011) examines the influence of financial institutions on the exercise of discretionary spending volatility for 25 EU countries. In an empirical analysis, the author uses the fiscal rule index (Fatás and Mihov, 2003), delegation index, and political, institutional, and macroeconomic variables (Rehman, 2021).

Similarly, Arsic et al. (2017) inquires the institutional and political determinants of discretionary fiscal policy in the case of 11 Central and Eastern European economies and observed no such evidence is observed for the fragmentation of the government. Similarly, Umoh et al. (2018) investigate the political economy of fiscal policy formation in West African countries and found (i) that fiscal policy in these economies remains persistent over time, which suggest that government in these economies or either unwilling or unable to adopt the counter-cycle policy, (ii) fiscal policy formation is based on the political and institutional factors rather than an economic system, (iii) the main factors defining fiscal perseverance include government effectiveness, corruption, and rule of law. Van et al. (2018) point out the need to strengthen existing regulations and corporate laws to control agency spending to reduce the financial turmoil. Sirimaneetham (2006) examines the factors that motivate policy volatility in less developed economies. Investigating policy uncertainty through the Bayesian approach, the author observes that policy volatility is more prevalent in countries that have a presidential system of government, minimum political constraints on policy formation, unstable government, and remained under British Empire. Likewise, inquiring about budget volatility, Agnello and Sousa (2009) examine various institutional, political, and economic factors in a panel of 125 economies. The results showed less democratic values and higher political instability is the main determinants of high deficit volatility. Furthermore, inquiring factors that cause a budget deficit in South Asia and ASEAN economies, Javid et al. (2011) considered institutional, political, and economic dimensions and observed that volatility in the budget deficit is significantly a

Associated with political and institutional variables. Whereas, corruption, unfavorable institutional setup (legal and bureaucratic), as well as ethnic, internal, and external conflicts, promote budget deficit volatility. Additionally, Mara (2012) revealed that only economic growth significantly dampens the budget balance volatility, while the other variables have no significant influence on budget volatility. Afonso and Hauptmeier (2009) observed that degree of decentralization of public spending, the existence of the effective fiscal rule, and the electoral cycle positively and significantly affect nation fiscal decisions. 


\section{Theoretical Background, Data and Econometric Methodology}

This section of the study provides a theoretical framework of our analysis, methodological strategy, and data.

\subsection{Theoretical Background}

There are three components of fiscal policy. First, the automatic stabilizing part, where the fiscal parameters automatically respond to fluctuations in the economic system without any intervention. Second, a systematic discretionary component is a part where a government systematically and deliberately responds to economic shocks to correct fluctuations. Third, a discretionary and non-systematic component is a part of the policy, where fiscal authorities exercise fiscal power independent of business cycle fluctuations. Alternatively, it is an exogenous part of fiscal policy, which is not associated with the current state of the economy rater such expenditure is made for political motives. To retrieve that exogenous discretionary part of the policy, this study amends the Fatas and Mihov (2003) who suggested fiscal rule equation by taking some additional variables such as the size of the nation, public debt, and tax revenue.

$$
G_{i t,}=\beta_{0}+\beta_{1} G_{i t-1}+\beta_{2} Y_{i t}+\theta^{\tau} \sum W_{i t}+\varepsilon_{i t}
$$

$G_{i t}$ is current real government expenditure, $G_{i t-1}$ is lag government expenditure, $Y_{i t}$ is real GDP, and $W_{i t}$ includes control variables like time trend, inflation rate, inflation rate square, size of the nation, public debt, and tax revenue. $\varepsilon_{i t}$ is the residual term. The $\varepsilon_{i t}$ the term is interpreted as non-systematic discretionary changes in policy, which is not related to cyclical fluctuations. To find the aggressiveness/volatility of the non-systematic discretionary component, this study uses three years moving average standard deviation of the residual term followed by Albuquerque (2011) and Fatás and Mihov (2003). In equation 2, $\delta_{i t}$ depicts volatility of non-systematic discretionary public spending.

$$
\delta_{i t}=\sqrt{\frac{\sum\left(\varepsilon_{i t}-\bar{\varepsilon}\right)^{2}}{n}}
$$

This study also inquires factors, which affect the behavior of non-systematic discretionary spending. For this purpose, the computed volatile discretionary part is regressed on the political, economic, and institutional indicators that explain the variation in the policy.

$\sigma_{i t}=\alpha_{0}+\alpha_{1} \sigma_{i t-1}+\beta^{\varphi} \sum I T_{i t}+\beta^{\pi} \sum M_{i t}+\mu_{i t}$

$\sigma_{i t-1}$ is the lag of non-systematic discretionary government expenditures, $I T_{i t}$ are institutionally related indicators like government stability $\left(g s_{i t}\right)$, political constraints $\left(p c_{i t}\right)$, bureaucratic quality $\left(b q_{i t}\right)$, political system $\left(p s_{i t}\right)$, and level of corruption $\left(c_{i t}\right)$. Where, $M_{i t}$ includes non-institutional variables, which consist of macroeconomic variables like GDP growth $\left(y_{i t}\right)$, population $\left(p_{i t}\right)$, and trade openness $\left(t o_{i t}\right), \mu_{i t}$ is the error term.

\subsection{Description of Sample Size and Data}

The study has employed a panel of developed and underdeveloped 55 economies throughout 1990-2019 (appendix Table A1). To dampen short-run disturbances in economic variables, the study has used the five year average data series (e.g 1990-1994, 1995-1999, 2000-2004, 2005-2009, 2010-2014, 2015-2019). This is a fair and standard approach used in various 
studies such as Perera and Lee (2013), Forbes (2000) and Dollar and Kraay (2003).

The data used in this study comprises real government expenditure, real GDP, inflation rate, size of nation, trade openness, public debt, tax revenue, political constraints, government stability, political system, level of corruption and non-systematic discretionary spending. The data sources are World Development Indicators (WDI), International Country Risk Guide (ICRG), Database of Political Institutions (DPI), and Political Constraints Index Database (POLCON), respectively.

\subsection{Estimation Technique}

Both the underline models, given in Equations 1 and 2, suffer from reverse causality, which is considered a potential source of endogeneity. For instance, in model 1, the level of GDP affects government spending (Wagner law), while in reverse government spending affects the level of GDP (Keynesian view). Similarly, in model 2, the level of GDP shapes the structure of non-systematic discretionary spending (Albuquerque, 2011), whereas in reverse the nonsystematic discretionary public spending affects the level of GDP (Fatas \& Mihov, 2003). Additionally, both the models incorporate lagged dependent variables on the right side. This situation leads to a correlation between lagged dependent variable and first-differenced error (Lee \& Azali, 2010).

The bias and inconsistent estimates can be observed and the lagged dependent variable will be correlated with the error term in the case of the OLS estimation method (Lee \& Azali, 2010). The results of the estimation techniques like OLS, fixed effect, and random effect produce bias simultaneity bias which cannot define the causal relationship. To overcome this problem, this study has employed the Generalized Method of Moment (GMM) to avoid the potential problems of endogeneity, heteroskedasticity and serial autocorrelation (Arellano \& Bond, 1991; Arellano \& Bover, 1995).

\section{Empirical Results}

The empirical results of the study have been discussed for the aggregate and disaggregate levels. The descriptive statistics are given in appendix tables A3, A4 and A5.

\subsection{Empirical Analysis (Aggregated)}

This study has estimated different panel models to examine the determinants of volatile nonsystematic discretionary public spending and the results have been reported in table 1 . However, due to different econometric problems, the study only relies on the estimates of the GMM technique. To check the appropriateness and adequacy of the model, the ArellanoBond AR (2) test and the Hansen test of over-identifying restrictions are employed. The probability values associated with Hansen and Arellano-Bond AR (2) tests are 0.591 and 0.362 respectively, confirming the exogenous and validity of instruments. Turning to the coefficients of the model, this study observes that lag of policy volatility $\left(\sigma_{i t-1}\right)$ appears positive and significant, which implies that current year policy behavior is significantly shaped by previous period policy trend. Furthermore, the persistent volatile practice of policy volatility results in spillover effects where such effects transfer significantly to upcoming periods. The coefficient associated to $\sigma_{i t-1}$ predicts that $47 \%$ volatility in current year nonsystematic discretionary spending is driven by the previous period non-systematic discretionary policy. 
It is interesting to note that almost all the institutional variables (except the corruption in one model) appear significant in all models, supporting the view that economic policies are the outcome of institutions. The political system $\left(p s_{i t}\right)$, i.e., the presidential form of government in comparison to the parliamentary nature of government significantly intensifies the volatility of non-systematic discretionary spending. The motivation for this intensifying outcome is that the power concentrates in fewer hands under the presidential system and the executives generally face lower restrictions on the budgetary process, which allows them to use more aggressive economic policies for their political motives. The coefficient with $p s_{i t}$ suggests that countries with greater intensity to the presidential system have a $23 \%$ higher likelihood of practicing the non-systematic discretionary policy in a more volatile fashion. This finding is closely matched to Fatás and Mihov (2003). Additionally, the political constraints $\left(p c_{i t}\right)$ on the executives significantly lower the use of volatile non-systematic discretionary policy. The sufficient number of constraints make accountable the policy makers, and restrain them to adopt politically motivated policies for their interest.

Table 1: Institutional and Non-Institutional Factors of Non-Systematic Discretionary Spending (Full Sample)

\begin{tabular}{|c|c|c|c|c|}
\hline Covariates & OLS & FE & RE & GMM \\
\hline \multirow[t]{2}{*}{$\sigma_{i t-1}$} & - & - & - & $0.471 * * *$ \\
\hline & & & & $(0.081)$ \\
\hline \multirow{2}{*}{$p s_{i t}$} & $0.316^{*}$ & $0.495^{*}$ & $0.580 * *$ & $0.230 * * *$ \\
\hline & $(0.167)$ & $(0.281)$ & $(0.248)$ & $(0.047)$ \\
\hline \multirow{2}{*}{$p c_{i t}$} & $-0.181^{* *}$ & $-0.216^{* * *}$ & $-0.431^{*}$ & $-0.523^{*}$ \\
\hline & $(0.079)$ & $(0.017)$ & $(0.236)$ & $(0.291)$ \\
\hline \multirow[t]{2}{*}{$g s_{i t}$} & $-0.294 * *$ & $-0.392 * * *$ & $-0.103^{*}$ & $-0.093 * *$ \\
\hline & $(0.131)$ & $(0.104)$ & $(0.052)$ & $(0.047)$ \\
\hline$b q_{i t}$ & $\begin{array}{c}-0.115^{* * *} \\
(0.040)\end{array}$ & $\begin{array}{c}-0.280 * * \\
(0.123)\end{array}$ & $\begin{array}{c}-0.138^{* *} \\
(0.066)\end{array}$ & $\begin{array}{c}-0.322 * * \\
(0.142)\end{array}$ \\
\hline \multirow[t]{2}{*}{$c_{i t}$} & 0.253 & $0.315^{* * * *}$ & $0.162^{*}$ & $0.146^{* * *}$ \\
\hline & $(0.475)$ & $(0.040)$ & $(0.095)$ & $(0.024)$ \\
\hline \multirow[t]{2}{*}{$y_{i t}$} & $-0.129 * *$ & -0.132 & $-0.345^{* *}$ & $-0.047 * * *$ \\
\hline & $(0.063)$ & $(0.351)$ & $(0.149)$ & $(0.019)$ \\
\hline \multirow[t]{2}{*}{$p_{i t}$} & -0.0864 & $-0.386^{*}$ & $-0.215^{* *}$ & $-0.128^{*}$ \\
\hline & $(0.140)$ & $(0.223)$ & $(0.101)$ & $(0.071)$ \\
\hline \multirow[t]{2}{*}{$t o_{i t}$} & 0.113 & 0.127 & -0.131 & $0.293^{*}$ \\
\hline & $(0.245)$ & $(0.659)$ & $(0.290)$ & $(0.160)$ \\
\hline \multirow[t]{2}{*}{ Constant } & 1.089 & $-3.106^{* * *}$ & $-2.417^{*}$ & $1.421^{* *}$ \\
\hline & $(0.850)$ & $(0.397)$ & $(1.295)$ & $(0.673)$ \\
\hline Observations & 330 & 330 & 330 & 330 \\
\hline Number of cross-sections & 55 & 55 & 55 & 55 \\
\hline $\begin{array}{l}\text { Hansen test of overid_restriction } \\
\text { P-Value }\end{array}$ & & & & 0.591 \\
\hline Arellano-Bond AR(2) P-Value & & & & 0.362 \\
\hline
\end{tabular}


Note: $*, * *$ and $* * *$ show $10 \%, 5 \%$ and $1 \%$ level of significance respectively. There are robust standard errors in parentheses.

The $p c_{i t}$ coefficient suggests that a unit increase in the political constraints significantly dampens spending volatility by $52 \%$. This finding is supported by the view of Duma (2015).Stability of the government $\left(g s_{i t}\right)$ lowers volatility of non-systematic discretionary policy. The finding regarding direction of coefficient is supported by the theory which suggests that stable form of public offices stabilizes economic policies and curtails uncertainty or volatile use of discretionary policies (Dutt \& Mobarak, 2016). The coefficient of $g s_{i t}$ implies that a unit increment in government stability lowers the incentives for exercising the volatile non-systematic discretionary policy by $9 \%$. Besides, the improvement in bureaucratic quality $\left(b q_{i t}\right)$ also restrain the hands of public office holders from the volatile use of non-systematic discretionary spending. It is viewed that incompetent bureaucracy as an agent can misinform the principal (government) about the outcomes of economic policies and can change the entire trajectory of policies (Blackburn et al. 2005). The $b q_{i t}$ coefficient suggests that a unit improvement in bureaucratic quality lower the non-systematic discretionary public spending by $0.32 \%$. Additionally, the level of corruption $\left(c_{i t}\right)$ incites the public authorities to assume the volatile use of non-systematic discretionary spending. The level of corruption makes the economic policies ineffective and diverts the inclusive level to the exclusive one (Hillman, 2004). The coefficient related to $c_{i t}$ implies that a unit increment in the level of corruption at the country level promotes the volatile non-systematic discretionary spending by almost $15 \%$.

Among the non-institutional factors, it is observed that GDP growth is negatively associated with the non-systematic discretionary policy. The coefficient associated with the growth suggests that a unit increase in growth dampens volatility in political spending by $5 \%$. This association is attributed to the fact that with economic development structural changes in an economy happen, which leads to lower the uncertainty of economic policies and specifically the chances of volatile use of non-systematic discretionary spending. This finding is supported by Fatas and Mihov (2013). Similarly, The significant and negative sign for the size of the nation implies a harmful influence on the volatility of discretionary public spending. The finding is similar to Furceri and Poplawski Ribeiro (2008), which suggests that a larger size of nation reduces the instability of fiscal policy. The associated coefficient suggests that a $1 \%$ increase in the size of the nation leads to lower discretionary policy volatility by $12 \%$. Unlike other covariates, openness has a positive and significant impact on policy volatility. This finding is in line with the study of Albuquerque (2011), who observed that openness promotes policy volatility.

\subsection{Empirical Analysis (Segregated)}

The geographic, institutional, and political backgrounds of different economies vary over time. So the diversity of these exogenous factors across the economies may create biases in results. Therefore, different fiscal rules and regulations across the group of countries may also create partial results for the aggregate sample (developed and developing countries). Figure A2 displays country wise volatility of the non-systematic discretionary spending. The graph shows that there prevails a significant diversification in fiscal policy discretion. Moreover, contrary to developed countries the developing countries are working on more volatile discretionary policies. Furthermore, fiscal choices are strictly conditional to fiscal guidelines in developed countries, hence restricting the authorities to exercise violent fiscal procedures. Whereas, the governments of the developing economies use violent discretion in spending because of the absence of policy restrictions. By keeping in view these differences 
of the discretionary fiscal regulations in developed and developing countries, it is essential to examine them separately.

\subsubsection{Comparative Analysis of Developing and Developed Economies}

Similar to the aggregated analysis, in this section, the study makes a comparative inquiry about the determinants of non-systematic discretionary spending by splitting the sample into developed and developing economies. Again the estimates of the GMM model show the probability values of Arellano-Bond AR (2) (0.192 and 0.351) and Hansen (0.273 and 0.181) tests endorse the validity and homogeneity of the instruments for both groups of economies.

The lags' discretionary policy volatility $\left(\sigma_{i t-1}\right)$ suggest a significant spillover effect of policy volatility for both sets of the sample. Nevertheless, such transfer is observed higher in magnitude for the developing economies. The coefficients associated with $\sigma_{i t-1}$ predict that $76 \%$, and $43 \%$ volatility in current year discretionary policy is driven by the previous years' policy trends for the developing and developed economies respectively. The reason behind the higher effect for developing economies is following the idea of the opportunistic political cycle by the politicians, according to which the politician maximize their probability of reelection (Nordhaus, 2001). However, in the developed economies the voters are very much fiscal conservatives, punishing high spending or deficits through polls. Various studies support the view that voters punish rather than reward election-year deficit spending (Brender \& Drazen, 2008; Kraemer, 1997; Peltzman, 1992). Additionally, in both the developed and developing economies the political system $\left(p s_{i t}\right)$ promote the volatile path of non-systematic discretionary spending. This suggests that developed countries with a presidential system have only $4 \%$ higher chances of using volatile non-systematic discretionary spending policy which even appear statistically insignificant, while with the same system the developing economies have almost 53\% higher chances of executing more volatile non-systematic discretionary spending policy. This explains that in developing countries, with highly concentrated power in fewer hands, the executives in developing countries intended to follow more volatile politically motivated policies for their enduring interest (Fatás \& Mihov, 2009). Unlike the presidential system, political constraints $\left(p c_{i t}\right)$ on the officials dampen the exercise of volatile non-systematic discretionary policy in both set of sample. However, the effect appears lower in magnitudes (only 4\%, and also insignificant) for the less developed economies as compared to the developed ones $(0.37 \%$, statistically significant). The finding suggests that with an additional level of constraints, though the use of volatile political.

Table 2: The Impact of Institutional and Non-Institutional Factors on Non-Systematic Discretionary Public Spending

\begin{tabular}{|c|c|c|c|c|c|c|c|c|}
\hline \multicolumn{5}{|c|}{ Developing Economies } & \multicolumn{4}{|c|}{ Developed Economies } \\
\hline Covariates & OLS & FE & $\mathbf{R E}$ & GMM & OLS & $\mathbf{F E}$ & RE & GMM \\
\hline$\sigma_{i t-1}$ & - & - & - & $0.761 * * *$ & - & - & - & $0.428 * * *$ \\
\hline & & & & $(0.036)$ & & & & $(0.001)$ \\
\hline$p s_{i t}$ & $0.164 * *$ & $0.107 * *$ & $0.358^{*}$ & $0.525^{* * *}$ & $0.073 * * *$ & $0.215^{*}$ & $0.109^{* * *}$ & 0.047 \\
\hline & $(0.064)$ & $(0.024)$ & $(0.197)$ & $(0.031)$ & $(0.004)$ & $(0.114)$ & $(0.037)$ & $(0.138)$ \\
\hline$p c_{i t}$ & $-0.279^{*}$ & $\begin{array}{c}- \\
0.128 * * *\end{array}$ & $-0.407 *$ & $\begin{array}{c}- \\
0.038\end{array}$ & $-0.279 *$ & $\begin{array}{c}- \\
0.128^{* * * *}\end{array}$ & $-0.407^{*}$ & $\begin{array}{c}- \\
0.371 * * *\end{array}$ \\
\hline
\end{tabular}




\begin{tabular}{|c|c|c|c|c|c|c|c|c|}
\hline & $(0.153)$ & $(0.039)$ & $(0.237)$ & $(0.521)$ & $(0.153)$ & $(0.039)$ & $(0.237)$ & $(0.107)$ \\
\hline \multirow[t]{2}{*}{$g s_{i t}$} & $-0.342 * *$ & $-0.192 *$ & $-0.531 * *$ & $\begin{array}{c}- \\
0.308 * * *\end{array}$ & $-0.421 *$ & $\begin{array}{c}- \\
0.125 * * *\end{array}$ & $\begin{array}{c}- \\
0.371 * * *\end{array}$ & $-0.215^{*}$ \\
\hline & $(0.235)$ & $(0.104)$ & $(0.239)$ & $(0.051)$ & $(0.225)$ & $(0.004)$ & $(0.071)$ & $(0.117)$ \\
\hline$b q_{i t}$ & $\begin{array}{l}-0.115^{*} \\
(0.063)\end{array}$ & $\begin{array}{c}- \\
0.420 * * * \\
(0.123)\end{array}$ & $\begin{array}{l}-0.036^{*} \\
(0.019)\end{array}$ & $\begin{array}{c}-0.431 * * \\
(0.212)\end{array}$ & $\begin{array}{c}- \\
0.415^{* * *} \\
(0.009)\end{array}$ & $\begin{array}{l}-0.320^{*} \\
(0.175)\end{array}$ & $\begin{array}{c}- \\
0.172 * * * \\
(0.025) \\
\end{array}$ & $\begin{array}{l}-0.185^{*} \\
(0.103)\end{array}$ \\
\hline \multirow[t]{2}{*}{$c_{i t}$} & $0.591 * * *$ & $0.159 * *$ & $0.403 * * *$ & $0.271 * *$ & $0.061 * * *$ & 0.281 & 0.051 & 0.114 \\
\hline & $(0.075)$ & $(0.072)$ & $(0.164)$ & $(0.124)$ & $(0.034)$ & $(0.171)$ & $(0.041)$ & $(0.291)$ \\
\hline \multirow[t]{2}{*}{$y_{i t}$} & $-0.309 * *$ & $-0.092 *$ & $0.452 * * *$ & $\begin{array}{c}- \\
0.175^{* * * *}\end{array}$ & $0.148 * * *$ & $\begin{array}{c}- \\
0.0609 * *\end{array}$ & $\begin{array}{c}- \\
0.263 * * *\end{array}$ & $-0.084 * *$ \\
\hline & $(0.163)$ & $(0.051)$ & $(0.039)$ & $(0.019)$ & $(0.0275)$ & $(0.0249)$ & $(0.0530)$ & $(0.041)$ \\
\hline \multirow[t]{2}{*}{$\overline{p_{i t}}$} & $-0.164 * *$ & $-0.186 * *$ & $\begin{array}{c}- \\
0.315^{* * * *}\end{array}$ & $-0.186^{*}$ & -0.202 & $\begin{array}{c}- \\
0.361 * * *\end{array}$ & $-0.125^{* *}$ & $-0.056^{*}$ \\
\hline & $(0.072)$ & $(0.092)$ & $(0.031)$ & $(0.103)$ & $(0.327)$ & $(0.092)$ & $(0.061)$ & $(0.031)$ \\
\hline \multirow[t]{2}{*}{$t o_{i t}$} & 0.587 & $0.744 * *$ & $0.241 * * *$ & $0.105 * *$ & $0.872 * * *$ & $-0.102 *$ & 0.0370 & $0.370 * * *$ \\
\hline & $(0.384)$ & $(0.368)$ & $(0.058)$ & $(0.050)$ & $(0.0211)$ & $(0.0577)$ & $(0.125)$ & $(0.125)$ \\
\hline \multirow[t]{2}{*}{ Constant } & $5.125 * * *$ & 1.696 & $2.405^{*}$ & $0.346^{* * *}$ & $0.919 * * *$ & $1.767 * * *$ & 2.697 & $-0.111 *$ \\
\hline & $(0.226)$ & (3.308) & $(1.325)$ & $(0.174)$ & $(0.181)$ & $(0.387)$ & $(2.596)$ & $(0.062)$ \\
\hline Observations & 198 & 198 & 198 & 198 & 132 & 132 & 132 & 132 \\
\hline $\begin{array}{l}\text { Number of cross- } \\
\text { sections }\end{array}$ & 33 & 33 & 33 & $\begin{array}{c}33 \\
0.273\end{array}$ & 22 & 22 & 22 & $\begin{array}{c}22 \\
0.181\end{array}$ \\
\hline \multicolumn{9}{|l|}{$\begin{array}{l}\text { Hansen test of } \\
\text { overid_restriction } \\
\text { P-Value }\end{array}$} \\
\hline $\begin{array}{l}\text { Arellano-Bond } \\
\text { AR(2) P-Value }\end{array}$ & & & & 0.192 & & & & 0.351 \\
\hline
\end{tabular}

Note: $* * *$ and $* * *$ show $10 \%, 5 \%$ and $1 \%$ level of significance respectively. There are robust standard errors in parentheses.

spending decrease, however, in developing economies bypassing such limits for the policy makers is not difficult because of the inefficient institutional environment (Hussain \& Siddiqi, 2013).

Similar to the political constraints, both the improvement in government stability $\left(g s_{i t}\right)$ and bureaucratic quality $\left(b q_{i t}\right)$ lower the volatile use of political spending in both natures of economies. However, it is quite interesting to note that the magnitude of both the covariates is larger in the case of developing economies. The reason for the higher effect is that developing economies largely suffer from government instability (Adefeso, 2018), and inappropriate bureaucratic system (Olowu, 1984), so when regimes stability and improvement in bureaucratic quality happen, there occur higher opportunities for more stable and growth supportive policies (Clague, 1994; Feng, 1997), and since the developed economies have reached to the threshold level of stable government and efficient bureaucratic quality (Acemoglu et al. 2003), therefore, further improvement, though lower the volatility of non-systematic discretionary polices, however, not by the same magnitude as that of less developed economies. Unlike the earlier two, corruption $\left(c_{i t}\right)$ further motivate the volatility of non-systematic discretionary public spending (Albuquerque, 2011). Yet, such an effect appears significant in the case of a less developed economy, where organized corruption 
inflates the spendings in unproductive activities (Sugata \& Neanidis, 2017: Yin \& Zhang, 2019). The coefficients of $c_{i t}$ suggest that one unit surge in corruption significantly enhances volatility in non-systematic discretionary spending by $27 \%$ in developing economies, while $12 \%$ in developed countries but not significantly.

In the set of non-institutional variables, it is observed that both the economic growth $\left(y_{i t}\right)$ and size of nation $\left(p_{i t}\right)$ has a negative impact on the policy volatility for both sets of economies. However, the effect appears larger in the case of developing economies (18\% and 19\%) as compared to developed ( $8 \%$ and 5\%). The reason behind the higher effect for developing economies is that in the transition course of economic development the less developed economies attain more reliable institutions (Boţa-Avram et al. 2018), which lowers the probability of exercising unnecessary economic policies. Similarly, with the already higher size of the nation, a further enhance in $p_{i t}$ decrease the policy volatility in developing economies, because of less exposed to idiosyncratic shocks (Furceri \& Poplawski Ribeiro, 2008).

Finally, the openness $t o_{i t}$ has a positive effect on policy volatility, however, the effect appears larger in the case of developed economies (37\%) as compared to developing economies $(10 \%)$. The greater magnitude in the case of the developed economy appears due to having a larger volume of world trade (Nguyen et al. 2020).

\section{Conclusion}

This study has envisioned inquiring the factors that affect the structure of non-systematic discretionary public spending for a mixed panel of developing and developed economies. By using the Generalized Method of Moment (GMM) estimation technique, this study performed the aggregated and disaggregated analysis according to the development level of the economies. The findings of the aggregated sample suggested that constraints on executives, government stability, bureaucratic quality, economic growth, and size of a nation significantly reduce the unpredictability of non-systematic discretionary public spending; nevertheless, the presidential system, corruption, and openness promoted such spending volatility. Additionally, the disaggregated analysis suggested that in developing economies, the constraints on executives insignificantly lowered the discretionary public spending volatility, while, the corruption and presidential system are insignificant in the case of developed economies that provide the evidence of instability in non-systematic discretionary spending there.

\section{References}

Acemoglu, D., Johnson, S., Robinson, J., \& Thaicharoen, Y. (2003). Institutional causes, macroeconomic symptoms: volatility, crises and growth. Journal of monetary economics, 50(1), 49-123.

Adefeso, H. (2018). Corruption, Political Instability and Development Nexus in Africa: A Call for Sequential Policies Reforms. Retrieved from https://ideas.repec.org/p/pra/mprapa/85277.html

Afonso, A., Agnello, L., \& Furceri, D. (2010). Fiscal policy responsiveness, persistence, and discretion. Public Choice, 145(3-4), 503-530.

Afonso, A., \& Hauptmeier, S. (2009). Fiscal behavior in the European Union: rules, fiscal decentralization and government indebtedness. Working paper No. NO 1054 / MAY 2009). Retrieved from https://www.ecb.europa.eu/pub/pdf/scpwps/ecbwp1054.pdf 
Agnello, L., \& Sousa, R. M. (2009). The determinants of public deficit volatility. Retrieved from

Albuquerque, B. (2011). Fiscal institutions and public spending volatility in Europe. Economic Modelling, 28(6), 2544-2559.

Alesina, A., \& Bayoumi, T. (1996). The costs and benefits of fiscal rules: evidence from US states. (National Bureau of Economic Research, Working Paper No. 5614). Retrieved from https://www.nber.org/papers/w5614

Alesina, A., \& Drazen, A. (1989). Why are stabilizations delayed?. (National Bureau of Economic Research, Working Paper No. 3053). Retrieved from https://www.nber.org/papers/w3053

Ali, A. M. (2005). Fiscal policy and economic growth: the effect of fiscal volatility. Journal of Business and Economics Research, 3(5).

Ali, M., \& Khan, K. (2020). Volatility in Discretionary Public Spending and Economic Growth: A Cross Country Analysis. The Pakistan Development Review, 59(1), 45-68.

Alt, J. E., \& Lowry, R. C. (1994). Divided government, fiscal institutions, and budget deficits: Evidence from the states. American Political Science Review, 88(4), 811-828.

Annett, M. A. (2006). Enforcement and the stability and growth pact: how fiscal policy did and did not change under Europe's fiscal framework: International Monetary Fund.

Arellano, M., \& Bond, S. (1991). Some tests of specification for panel data: Monte Carlo evidence and an application to employment equations. The review of economic studies, 58(2), 277-297.

Arellano, M., \& Bover, O. (1995). Another look at the instrumental variable estimation of error components models. Journal of econometrics, 68(1), 29-51.

Arsic, M., Nojkovic, A., \& Randjelovic, S. (2017). Determinants of discretionary fiscal policy in Central and Eastern Europe. Economic Systems, 41(3), 367-378.

Badinger, H. (2009). Fiscal rules, discretionary fiscal policy, and macroeconomic stability: an empirical assessment for OECD countries. Applied Economics, 41(7), 829-847.

Barro, R. J. (1979). On the determination of the public debt. Journal of Political Economy, 87(5, Part 1), 940-971.

Blackburn, K., Bose, N., \& Haque, M. E. (2005). Public expenditures, bureaucratic corruption and economic development. Centre for Growth and Business Cycle Research Discussion Paper Series, 53(13), 417-458.

Boţa-Avram, C., Groşanu, A., Răchişan, P.-R., \& Gavriletea, M. D. (2018). The Bidirectional Causality between Country-Level Governance, Economic Growth and Sustainable Development: A Cross-Country Data Analysis. Sustainability, 10(2), 502.

Brender, A., \& Drazen, A. (2008). How do budget deficits and economic growth affect reelection prospects? Evidence from a large panel of countries. American economic review, 98(5), 2203-2220.

Clague, C. (1994). Bureaucracy and economic development. Structural Change and Economic Dynamics, 5(2), 273-291.

Debrun, X., Moulin, L., Turrini, A., Ayuso-i-Casals, J., \& Kumar, M. S. (2008). Tied to the mast? National fiscal rules in the European Union. Economic Policy, 23(54), 298-362.

Dixit, A., \& Lambertini, L. (2001). Monetary-fiscal policy interactions and commitment versus discretion in a monetary union. European Economic Review, 45(4-6), 977-987.

Dollar, D., \& Kraay, A. (2003). Institutions, trade, and growth. Journal of monetary economics, 50(1), 133-162.

Duma, D. (2015). Political Constraints and Discretionary Fiscal Policy during the Recent Economic Crisis. Romanian Journal of Political Science, 15(2), 126.

Dutt, P., \& Mobarak, A. M. (2016). Democracy and policy stability. International Review of Economics \& Finance, 42, 499-517. 
Fabrizio, S., \& Mody, A. (2006). Can budget institutions counteract political indiscipline? Economic Policy, 21(48), 690-739.

Fatas, A., \& Mihov, I. (2013). Policy volatility, institutions, and economic growth. Review of Economics and Statistics, 95(2), 362-376.

Fatás, A., \& Mihov, I. (2003). The case for restricting fiscal policy discretion. The Quarterly Journal of Economics, 118(4), 1419-1447.

Fatás, A., \& Mihov, I. (2009). Macroeconomic Policy: Does it Matter for Growth?; the Role of Volatility: World Bank.

Feng, Y. (1997). Democracy, political stability and economic growth. British Journal of Political Science, 27(3), 391-418.

Forbes, K. J. (2000). A reassessment of the relationship between inequality and growth. American economic review, 90(4), 869-887.

Furceri, D., \& Poplawski Ribeiro, M. (2008). Government Consumption Volatility and Country Size. Centre D'tudes Prospectives et D'Informations Internationales Working Paper, 17.

Gleich, H. (2003). Budget institutions and fiscal performance in Central and Eastern European countries.

Hallerberg, M., Strauch, R., \& Von Hagen, J. (2007). The design of fiscal rules and forms of governance in European Union countries. European Journal of Political Economy, 23(2), 338-359.

Henisz, W. J. (2000). The institutional environment for economic growth. Economics \& Politics, 12(1), 1-31.

Hillman, A. L. (2004). Corruption and public finance: an IMF perspective. European Journal of Political Economy, 20(4), 1067-1077.

Hussain, T., \& Siddiqi, M. W. (2013). Fiscal Policy, Institutions and Governance in Selected South Asian Countries. Pakistan Journal of Commerce \& Social Sciences, 7(2).

Javid, A. Y., Arif, U., \& Arif, A. (2011). Economic, political and institutional determinants of budget deficits volatility in selected Asian countries. The Pakistan Development Review, 649-662.

Khan, K., Ali, M., \& Iqbal, N. (2019). Volatile Discretionary Public Spending and Economic Growth: A Comparative Evidence of Developed and Developing Countries. Pakistan Business Review, 20(2), 403-416.

Kraemer, M. (1997). Electoral budget cycles in Latin America and the Caribbean: incidence, causes, and political futility.

Lane, P. R. (2003). The cyclical behavior of fiscal policy: evidence from the OECD. Journal of Public Economics, 87(12), 2661-2675.

Lee, H.Y., \& Azali, M. (2010)The endogeneity of the Optimum Currency Area criteria in East Asia. Economic Modelling, 27(1), 165-170.

Mara, E. (2012). Determinants of fiscal budget volatility in old versus new EU member states.

Nguyen, H. M., Quan, B. Q. M., Le, H. V., \& Tran, T. V. (2020). Determinants of intraindustry trade between Vietnam and countries in TPP. The Journal of Asian Finance, Economics, and Business, 7(1), 123-129.

Nordhaus, W. (2001). The Political Business Cycle', Review of Economic Studies, XLII (2), April, 169-90. INTERNATIONAL LIBRARY OF CRITICAL WRITINGS IN ECONOMICS, 131, 316-337.

Olowu, D. (1984). Bureaucratic performance in developed and developing countries: A review of recent literature and developments: JSTOR.

Peltzman, S. (1992). Voters as fiscal conservatives. The Quarterly Journal of Economics, 107(2), 327-361. 
Perera, L. D. H., \& Lee, G. H. (2013). Have economic growth and institutional quality contributed to poverty and inequality reduction in Asia? Journal of Asian Economics, 27, 71-86.

Persson, T. (2002). Do political institutions shape economic policy? Econometrica, 70(3), 883-905.

Persson, T., \& Tabellini, G. (2001). Political institutions and policy outcomes: what are the stylized facts?

Poterba, J. M. (1994). State responses to fiscal crises: The effects of budgetary institutions and politics. Journal of Political Economy, 102(4), 799-821.

Rehman, M. Z. (2021). The Macroeconomic and Institutional Drivers of Stock Market

Development: Empirical Evidence from BRICS Economies. The Journal of Asian Finance,

Economics, and Business, 8(2), 77-88.

Sinha, P., Arora, V., \& Bansal, V. (2011). Determinants of Public Debt for middle income and high income group countries using Panel Data regression.

Sirimaneetham, V. (2006). Explaining policy volatility in developing countries. Bristol Economics Discussion Papers, 6, 583.

Soetjipto, N., Kurniawan, G., Sulastri, S., \& Riswanto, A. (2020). Supply Chain Analysis in Public Works: The Role of Work Climate, Supervision and Organizational Learning. The Journal of Asian Finance, Economics, and Business, 7(12), 1065-1071.

Sugata, G., \& Neanidis, K. (2017). Corruption, fiscal policy, and growth: a unified approach. The BE Journal of Macroeconomics, 17(2).

Umoh, O. J., Onye, K. U., \& Atan, J. A. (2018). Political and Institutional Determinants of Fiscal Policy Persistence in West Africa. University Library of Munich, Germany.

Van Son Lai, D. K. N., Sodjahin, W., \& Soumare, I. (2018). Discretionary Idiosyncratic Risk, Firm Cash Holdings, and Investment', Advances in Pacific Basin Business, Economics and Finance (Advances in Pacific Basin Business, Economics and Finance, Volume 6, 51-75.

Wyplosz, C. (2005). Fiscal policy: institutions versus rules. National Institute Economic Review, 191(1), 64-78.

Yin, H., \& Zhang, R. (2019). The nature of controlling shareholders, political background and corporate anti-corruption practice disclosure. The Journal of Asian Finance, Economics, and Business, 6(1), 47-58.

Yläoutinen, S. (2004). The role of electoral and party systems in the development of fiscal institutions in the Central and Eastern European countries. Bonn: ZEI 
Appendix:

Figure A1: Volatile Behavior of Non-Systematic Discretionary Spending

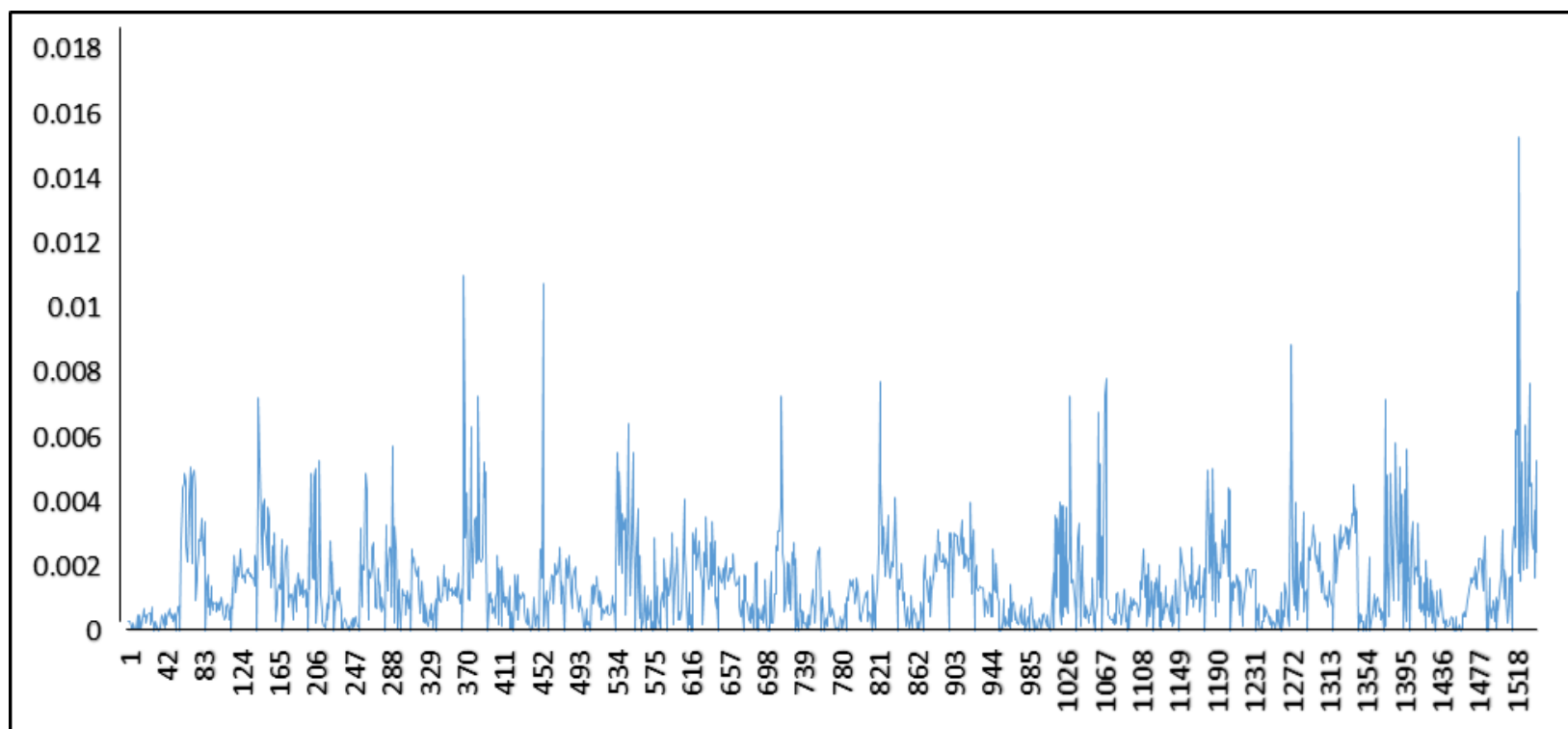

Note: the authors' own calculation, based on the standard deviation of the non-systematic discretionary expenditure

Figure A2: Country Wise Non-Systematic Discretionary Spending Volatility

\begin{tabular}{|c|c|c|c|c|c|c|c|}
\hline Austrilia & Austria & Bangladesh & Balgeium & Bolivia & Botswana & Brazil & Cameroon \\
\hline Canada & China & Colombia & Costa Rica & Denmark & Dominican & Ecuador & Egypt \\
\hline EI Salvador & Finland & France & Gabon & Greece & Guatemala & Hondruras & Iceland \\
\hline India & Indonesia & Ireland & $\underset{\text { Italy }}{\text { Mv }}$ & Japan & Kenya & South Korea & Mexico \\
\hline Morocco & Netherlands & New Zealand & Norway & Pakistan & & Peru & Philippines \\
\hline Portugal & Senegal & Singapore & South Africa & $\begin{array}{l}\text { MMWh } \\
\text { Spain }\end{array}$ & Mri Lanka & Sweden & Switzerland \\
\hline Thailand & Togo & Turkey & United Kingdom & United States & Uruguay & Zambia & $M$ \\
\hline mortm & MWM & rhannm & $\mathrm{m}^{-}$ & $\sim^{\prime m}$ & mon & & \\
\hline \multicolumn{8}{|c|}{ Time } \\
\hline
\end{tabular}

Note: Authors' own calculation based on the standard deviation of discretionary expenditure. 
Table A1 : List of Sample Economics

\begin{tabular}{llllll}
\hline Developed Sample & \multicolumn{2}{l}{ Developing Sample } & & \\
\hline 1 & Australia & 23 & Bangladesh & 45 & Panama \\
\hline 2 & Austria & 24 & Bolivia & 46 & Peru \\
\hline 3 & Belgium & 25 & Botswana & 47 & Philippines \\
\hline 4 & Canada & 26 & Brazil & 48 & Senegal \\
\hline 5 & Denmark & 27 & Cameroon & 49 & South Africa \\
\hline 6 & Finland & 28 & China & 50 & Sri Lanka \\
\hline 7 & France & 29 & Colombia & 51 & South Africa \\
\hline 8 & Greece & 30 & Costa Rica & 52 & Thailand \\
\hline 9 & Iceland & 31 & Dominican Republic & 53 & Togo \\
\hline 10 & Ireland & 32 & Ecuador & 54 & Turkey \\
\hline 11 & Italy & 33 & Egypt & 55 & Zambia \\
\hline 12 & Japan & 34 & El Salvador & & \\
\hline 13 & Netherland & 35 & Gabon & & \\
\hline 14 & New Zealand & 36 & Guatemala & & \\
\hline 15 & Norway & 37 & Honduras & & \\
\hline 16 & Portugal & 38 & India & & \\
\hline 17 & Singapore & 39 & Indonesia & & \\
\hline 18 & Spain & 40 & Kenya & & \\
\hline 19 & Sweden & 41 & Korea & & \\
\hline 20 & Switzerland & 42 & Mexico & & \\
\hline
\end{tabular}

Table A2: Definition of Variables

\begin{tabular}{l|l|l}
\hline \multicolumn{1}{c|}{ Variables } & \multicolumn{1}{c}{ Definitions } & \\
\hline $\begin{array}{l}\text { Discretionary } \\
\text { Spending }\end{array}$ & $\begin{array}{l}\text { The form of public spending which is not associated with the business } \\
\text { cyclical fluctuations of the economy. The data is constructed through } \\
\text { the five years standard deviations of the residuals of the fiscal rule } \\
\text { model. }\end{array}$ & Own Developed \\
\hline Government & $\begin{array}{l}\text { General government final consumption expenditure (formerly general } \\
\text { government consumption) includes all government current } \\
\text { expenditures for purchases of goods and services (including } \\
\text { compensation of employees). It also includes most expenditures on } \\
\text { national defense and security, but excludes government military } \\
\text { expenditures that are part of government capital formation. Data are } \\
\text { in constant U.S. dollars (2005). }\end{array}$ & WDI \\
\hline Size f Nation & $\begin{array}{l}\text { It is the total population which is based on the de facto definition } \\
\text { of population, which counts all residents regardless of legal status or } \\
\text { citizenship. The values shown are midyear estimates. }\end{array}$ & WDI \\
\hline Trade Openness & $\begin{array}{l}\text { Trade is the sum of exports and imports of goods and services } \\
\text { measured as a share of gross domestic product. }\end{array}$ & WDI \\
\hline Inflation & $\begin{array}{l}\text { Inflation as measured by the consumer price index reflects the annual } \\
\text { percentage change in the cost to the average consumer of acquiring a } \\
\text { basket of goods and services that may be fixed or changed at specified } \\
\text { intervals, such as yearly. }\end{array}$ & WDI \\
\hline GDP Per Capita & $\begin{array}{l}\text { GDP per capita is gross domestic product divided by mid-year } \\
\text { population. GDP is the sum of gross value added by all resident } \\
\text { producers in the economy plus any product taxes and minus any } \\
\text { subsidies not included in the value of the products. It is calculated } \\
\text { without making deductions for depreciation of fabricated assets or for } \\
\text { depletion and degradation of natural resources. Data are in constant }\end{array}$ & \\
\hline
\end{tabular}




\begin{tabular}{|c|c|c|}
\hline & 2005 U.S. dollars. & \\
\hline $\begin{array}{l}\text { Political } \\
\text { Constraints }\end{array}$ & $\begin{array}{l}\text { The index can be used to determine the constraints faced by } \\
\text { politicians desiring to change a status quo policy in a country in a } \\
\text { given year. Scale } 0 \text { (most hazardous - no checks and balances) to } 1 \\
\text { (most constrained - extensive checks and balances). Measure the } \\
\text { feasibility of change in policy given the structure of a nation's } \\
\text { political institutions and the preference of the actors that inhabit them. }\end{array}$ & $\begin{array}{l}\text { POLCON } \\
\text { (Henisz data set) }\end{array}$ \\
\hline $\begin{array}{l}\text { Government } \\
\text { Stability }\end{array}$ & $\begin{array}{l}\text { This is an assessment both of the government's ability to carry out its } \\
\text { declared program(s), and its ability to stay in office. The risk rating } \\
\text { assigned is the sum of three subcomponents i.e. (Government Unity, } \\
\text { Legislative Strength and Popular Support) each with a maximum } \\
\text { score of } 1 \text { point which equates to Very Low Risk and a minimum } \\
\text { score of } 0 \text { points which shows Very High Risk. }\end{array}$ & ICRG \\
\hline Corruption & $\begin{array}{l}\text { This is an assessment of corruption within the political system which } \\
\text { is a threat to foreign investment for several reasons: it distorts the } \\
\text { economic and financial environment; introduces the efficiency of } \\
\text { government and business by enabling people to assume positions of } \\
\text { power through patronage rather than ability; and, last but not least, } \\
\text { introduces an inherent instability into the political process. The value } \\
0 \text { indicates lower corruption level and closer to higher corruption } \\
\text { level in the country. }\end{array}$ & ICRG \\
\hline Political System & $\begin{array}{l}\text { In order to capture the Political system of the country we are using } \\
\text { Dummy variable which assigns } 1 \text { for presidential system and } 0 \text { for } \\
\text { parliamentary system. With five year averages, the value close to } 1 \\
\text { indicates that count has more intensity towards presidential system } \\
\text { and otherwise the parliamentary system. }\end{array}$ & ICRG \\
\hline
\end{tabular}

Note: all variables are averaged over the five years from 1990 to 2019.

Table A3: Descriptive Summary of the Variables for Full Sample

\begin{tabular}{lccccc}
\hline Indicators & No. of Obs. & Mean & Std. Dev. & Min. & Max. \\
\hline Government Expenditures & 330 & 104000 & 267000 & 133 & 2160000 \\
\hline Per Capita GDP & 330 & 14885.65 & 16412.72 & 255.6 & 67804.5 \\
\hline Tot. Population & 330 & 79 & 212 & 0.241 & 1350 \\
\hline CPI Inflation & 330 & 64.44 & 30.325 & 4.23 & 124.71 \\
\hline Eco. Growth (GDP) & 330 & 3.502 & 3.50 & -17.14 & 19.44 \\
\hline Trade Openness & 330 & 70.38 & 49.98 & 0.83 & 439.65 \\
\hline Political System & 330 & 0.44 & 0.49 & 0 & 1 \\
\hline Political Constraints & 330 & 0.52 & 0.29 & 0 & 0.89 \\
\hline Government Stability & 330 & 0.64 & 0.16 & 0.08 & 0.935 \\
\hline Corruption & 330 & 0.57 & 0.24 & 0.34 & 0.86 \\
\hline Bureaucratic Quality & 330 & 0.63 & 0.45 & 0.2935 & 0.85 \\
\hline
\end{tabular}

Table A4: Development Economics: Descriptive Statistics

\begin{tabular}{lcccc|c}
\hline Indicators & No. of Obs. & Mean & Std. Dev. & Min. & Max. \\
\hline Government Expenditures & 132 & 220000 & 387000 & 2030 & 2160000 \\
\hline Per Capita GDP & 132 & 32896.61 & 10903.67 & 10406.7 & 67804.55 \\
\hline Tot. Population & 132 & 34.9 & 60.5 & 0.2414 & 314 \\
\hline CPI Inflation & 132 & 78.4707 & 18.4001 & 13.3837 & 110.0195 \\
\hline Eco. Growth (GDP) & 132 & 2.5061 & 2.7417 & -8.5386 & 15.2403 \\
\hline Trade Openness & 132 & 82.9261 & 68.3459 & 15.9239 & 439.6567 \\
\hline Political System & 132 & 0.0454 & 0.2084 & 0 & 1 \\
\hline
\end{tabular}




\begin{tabular}{lllll|c}
\hline Political Constraints & 132 & 0.7467 & 0.1740 & 0.0133 & 0.8943 \\
\hline Government Stability & 132 & 0.6810 & 0.1332 & 0.2638 & 1 \\
\hline Corruption & 132 & 0.8057 & 0.1648 & 0.3333 & 0.6742 \\
\hline Bureaucratic Quality & 132 & 0.7461 & 0.2223 & 0.38761 & 0.9411 \\
\hline
\end{tabular}

Table A5: Development Economics: Descriptive Statistics

\begin{tabular}{lccccc}
\hline Indicators & $\begin{array}{c}\text { No. of } \\
\text { Obs. }\end{array}$ & Mean & Std. Dev. & Min. & Max. \\
\hline Government Expenditures & 198 & 40900 & 92500 & 133 & 618000 \\
\hline Per Capita GDP & 198 & 6501.93 & 10838.23 & 0.33 & 58009.82 \\
\hline Tot. Population & 198 & 101 & 255 & 0.24 & 1350 \\
\hline CPI Inflation & 198 & 57.62 & 32.41 & 3.23 & 124.71 \\
\hline Eco. Growth (GDP) & 198 & 3.91 & 3.77 & -17.14 & 19.44 \\
\hline Trade Openness & 198 & 64.19 & 31.64 & 0.83 & 198.78 \\
\hline Political System & 198 & 0.62 & 0.49 & 0 & 1 \\
\hline Political Constraints & 198 & 0.42 & 0.28 & 0 & 0.74 \\
\hline Government Stability & 198 & 0.62 & 0.17 & 0 & 0.52 \\
\hline Corruption & 198 & 0.47 & 0.20 & 0.41 & 1 \\
\hline Bureaucratic Quality & 198 & 0.58 & 0.46 & 0.24 & 0.61 \\
\hline
\end{tabular}

